\title{
A Ráckevei (Soroksári) Duna-ág integrált tervezése a fenntartható vízgazdálkodás érdekében
}

\section{Integrated Planning of the Ráckeve (Soroksár) Branch of the Danube for Sustainable Water Management}

\begin{abstract}
A Ráckevei (Soroksári) Duna (RSD) egy stratégiai jelentöségü vízgazdálkodási rendszer. Az RSDvel kapcsolatban komplex igények jelentkeznek, amelyek összehangolása jelentös kihívást jelent. Az éghajlatváltozás következtében egyre nagyobb valószínüséggel elöforduló kisvizes időszakok mennyiségi és minőségi problémákhoz vezethetnek. A klímaváltozás tükrében dinamikusan változó igények, illetve tervezési körülmények hatására sérülhet a rendszer funkciójának ellátása. A vízrendszer kiterjedéséből és komplexitásából adódóan, egy esetleges fejlesztés során, nagy beruházási és üzemeltetési költségekkel kell kalkulálni. A rendszer müködésébe történő beavatkozások visszahatnak egymásra, ezért kritikus kérdés a forrásfelhasználás hatékonyságának biztositása. A tudományos közlemény célja, hogy stratégiai szemléletü komplex tervezés alkalmazásával minimalizálja a kockázatokat. A közlemény szerzője feltárja a rendszerszintü komplex megoldási lehetőségeket. A kutatási eredmények hozzájárulnak az RSD vízminőségi állapotának költséghatékony javitásához, továbbá elősegítik a hatékony üzemeltetést.
\end{abstract}

Kulcsszavak: vízrendszer, vízminöség, fenntartható vízgazdálkodás, vízhasználatok, komplex tervezés

Ráckeve (Soroksár) Danube (RSD) is a water system with strategic significance. Complex demands occur related to the RSD system. Harmonisation of different demands means a significant challenge. Due to climate change low water levels occur more likely and that leads to water quality and quantity problems. With regard to climate change, due to the effect of dynamically changing demands and design conditions, the functioning of the system might be damaged. High investment and operating costs need to be calculated during a possible development process, due to the scope

Nemzeti Közszolgálati Egyetem, doktori hallgató, e-mail: tothtamas@live.com, ORCID: https://orcid.org/00000003-2810-0583 
and complexity of the system. Interventions in the operation of the system are interacting with each other, therefore the support of efficient resource management is a crucial question. The main objective of this article is to minimise the risks with the application of strategic approach to complex planning. The author of this article reveals system based complex solutions. Research results facilitate the cost-efficient improvement of the water quality status of the $R S D$, furthermore, they support effective operation.

Keywords: water system, water quality, sustainable water management, water uses, complex planning

\section{Bevezetés}

A Duna, Magyarország legnagyobb folyójaként, Budapestet átszelve a Csepel-szigetnél elágazik. A Duna főágától - a folyás iránya szerint - balra található víztest a Ráckevei (Soroksári) Duna-ág (RSD) nevet viseli. Az RSD földrajzi szempontból egyszerűen értelmezhető, viszont részletesen megvizsgálva megállapítható, hogy az RSD nem egyszerüen a Duna egy mellékága, hanem egy stratégiai jelentőségű vízgazdálkodási rendszer. Élővilága igen gazdag és speciális élettérnek tekinthető a Duna főágával összehasonlítva. ${ }^{2}$ Az RSD ökológiai állapotát, a különböző fellelhető fajokat számos kiváló szakember kutatta az elmúlt évtizedekben. Az élővilága jól tükrözi az erősen módosított jellegű víztest változékony, számos esetben szélsőséges vízminőséggel jellemezhető viszonyait. ${ }^{3}$ Érdekességként megemlíthető, hogy a vízfolyás halfaunájáról már 1902-ből is található forrás. ${ }^{4}$ A teljes RSD-rendszer, különböző módokon, mintegy 200 ezer embert érint. ${ }^{5} \mathrm{Az}$ RSD-vel kapcsolatban komplex igények jelentkeznek, amelyek összehangolása jelentős kihívást jelent.

Az éghajlatváltozás következtében egyre nagyobb valószínűséggel előforduló kisvizes időszakok mennyiségi és minőségi problémákhoz vezethetnek. A különböző használatok és terhelések következtében az elmúlt évek alatt a víztest jelentősen feliszapolódott. ${ }^{6}$ A nyári időszakot jellemző alacsony vízállások, a feliszapolódottság mértéke és a folyamatos terhelések együttesen negatív hatással vannak a vízminőségre. A klímaváltozás tükrében dinamikusan változó igények, illetve tervezési körülmények hatására sérülhet a rendszer funkciójának ellátása.

2 Vadadi-Fülöp Csaba - Mészáros Gergely: A Ráckevei-Soroksári Dunával kapcsolatos zooplankton és makrogerinctelen kutatások áttekintése. Hidrológiai Közlöny, 87. (2007), 3. 60-63.

3 Csányi Béla - Juhász Péter - Tyahun Szabolcs: A Ráckevei Soroksári Duna makroszkópikus vízi gerincteleinek vizsgálata. Vízügyi Közlemények, 84. (2002), 2. 174-193.

4 Répássy Miklós: Az angolnáról. Halászat, 3. (1902), 1. 93-95.

5 Jelentős vízgazdálkodási problémák - Duna-völgyi-föcsatorna vízgyüjtő-gazdálkodási tervezési alegység.

6 Papanek László: Az újonnan épülö vízleeresztő mütárgy szerepe a Ráckevei/Soroksári/Duna-ág vízgazdálkodásában. Előadás. 
Felmerül a kérdés, hogyan lenne környezeti és gazdasági szempontból hatékonyan javítható az RSD vízminőségi állapota.

Feltételezem, hogy a vízrendszer kiterjedéséből és komplexitásából adódóan, egy esetleges fejlesztés során, nagy beruházási és üzemeltetési költségekkel kell kalkulálni. A rendszer müködésébe történő beavatkozások visszahatnak egymásra, ami arra enged következtetni, hogy neuralgikus pont lesz a forrásfelhasználás hatékonyságának biztosítása.

A tudományos közlemény célja, hogy stratégiai szemléletű komplex tervezés alkalmazásával minimalizálja a kockázatokat.

A célkitűzés teljesítése érdekében a kutatásom keretében feltártam a vízminőségi állapot hatékony javításához szükséges rendszerszintű komplex megoldási lehetőségeket. A közlemény hozzájárul az RSD vízminőségi állapotának költséghatékony javításához, továbbá elösegíti a hatékony üzemeltetést. Mindemellett hozzájárul a lehetséges beruházások tervezésének és ütemezésének előzetes megalapozásához.

\section{A vízrendszer bemutatása}

Az RSD-vízrendszert két nagy vízépítési mütárgy határolja. A rendszert felülről a Kvassayzsilippel, alulról a Tassi-zsilippel lehet szabályozni. A Kvassay-mütárgy fő feladatai: a vízpótlás és az üzemvízszint biztosítása megfelelő dunai vízállás esetén. Emellett a hajózsilip lehetővé teszi a hajózást. Magas dunai vízállás esetén a vízpótlás során energiatermelésre is alkalmas a mütárgy. A Kvassay-mütárgy a fővédvonal részeként nem utolsósorban fontos árvízvédelmi funkciót is ellát. Alacsony vízállás esetén a gravitációs vízbetáplálás lehetősége megszűnik. Ebben az esetben az vízerőmű turbinái szivattyúként tudják beemelni a vizet mellékágba. A jelenleg meglévő Tassi-műtárgy szintén az elsőrendű árvízvédelmi rendszer részét képezi. Az RSD átnézeti helyszínrajzát az 1. ábra szemlélteti.

Az RSD alapparamétereit megvizsgálva a következő jellemző értékek mértékadók: a szakasz hossza: $\sim 57,3 \mathrm{~km}$, az átlagos felülete $\sim 16 \mathrm{~km}^{2}$, átlagos vízmélysége $2,5 \mathrm{~m}$, átlagos víztérfogata mintegy 40 millió $\mathrm{m}^{3}$. Az RSD a felszínesését megvizsgálva a vízrendszer jellegében állóvíz víztestnek minősíthető. A Kvassay-zsilipen keresztül évente 550-750 millió $\mathrm{m}^{3}$ vizet táplálnak be, de gyakorlatilag nincs sodorvonala a mellékágnak. Az RSD vízszintesése a Kvassay- és a Tassi-nagymútárgy között mindössze átlagosan 10-30 cm (2019. 03. 24. 10:00-kor = 19,5 cm), amely jelentős eltérést mutat a nagy Duna vízszinteséséhez képest az adott szakaszon, amely átlagosan 4-5 m (2019. 03. 24. 10:00-kor = 4,705 m). ${ }^{7}$

7 Operatív vízállások. Vízügyi Honlap. 


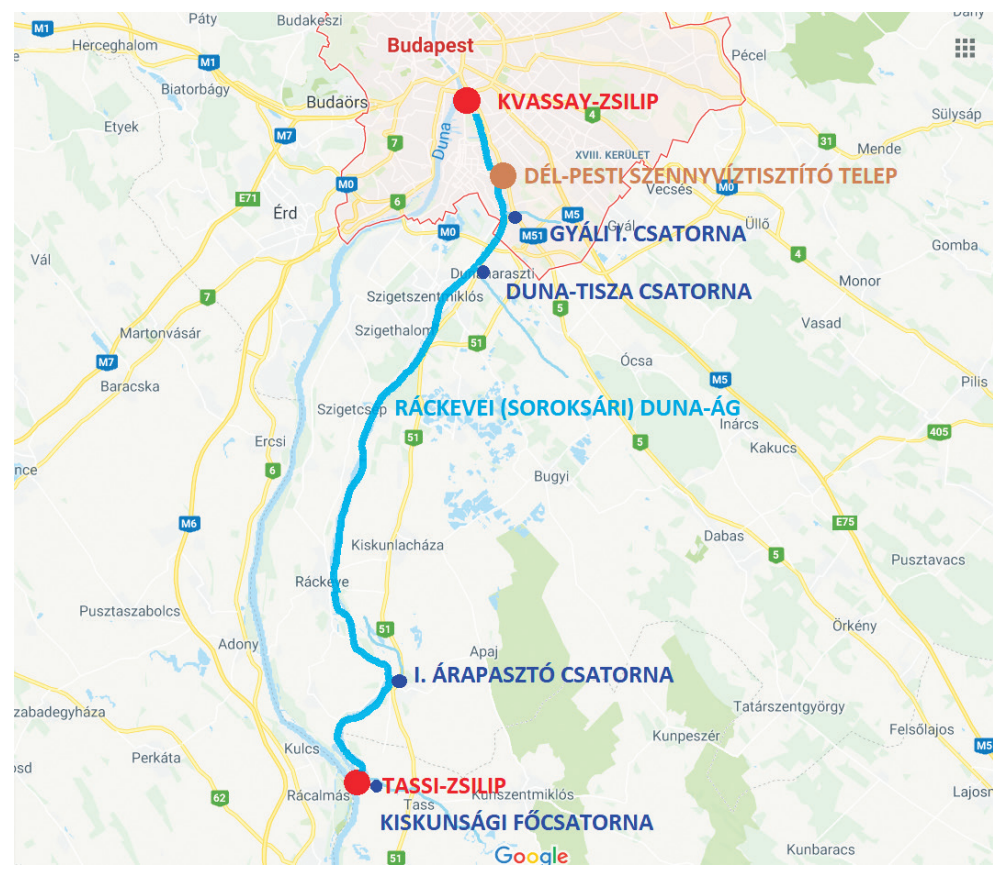

1. ábra. Ráckevei (Soroksári) Duna-ág

Forrás: a szerző szerkesztése a Google Maps alapján

Az RSD felépítése és morfológiai viszonyai az évszázadok során folyamatosan változtak. A Duna a folyómeder szabályozását megelőzően, a Gellért-hegy alatti folyószakaszon mintegy 1000 méteres mederszélességet is felvehetett, amely különvált a budafoki és a soroksári Duna-ágra. A rendszeres árvizek következtében elengedhetetlenné vált a Duna mederrendezése.

„Hogy a Duna-folyam Buda-Pest mellett akképen szabályoztathassék, a mint a hajózás és kereskedés országos érdekei igénylik s a föváros, mint az ipar és kereskedelem központja, oly állásba emeltessék, mely számára a szabad közlekedés mindazon előnyeit biztositsa, a melyek az ipar és kereskedés fejlődésének nélkülözhetlen feltételei: felhatalmaztatik a ministerium, hogy ezen országos czélból szükséges beruházásokra huszonnégy millió osztr. ért. forint erejéig sorsolási kölcsönt köthessen." ${ }^{8}$

A 19. század második felében, az osztrák-magyar kiegyezést követő időszakban, a folyószabályozások eredményeként északról elzárták a soroksári folyóágat. Az elzárt folyóág déli részén található területeket viszont továbbra is, többször elöntötte az árvíz. Az árvizek és a hajózhatóság hiánya további beavatkozásokat tett szükségessé. Az 1904. évi XIV. törvénycikk III. fejezet 4. bekezdés e) pontjában az Országgyủlés elrendelte a Soroksári Duna-ág rendezését és hajózhatóvá tételét és 5 millió K hitelösszeget engedélyeztettek a „földmivelésügyi tárcza” körében. A törvénycikk érdekessége, hogy korabeli „salátatörvény” volt, amely alapvetően

8 1870. évi X. törvénycikk a Duna-folyamnak a főváros mellett szabályozásáról s a forgalom és közlekedés érdekében Buda-Pesten létesitendő egyéb közmunkák költségeinek fedezéséröl és e közmunkák végrehajtási közegeiről. 
a vasúti hálózat fejlesztéséről szólt („a magyar királyi államvasutak hálózatának kibővítéséről, vasuti és más beruházásokról, valamint a szükséges költségek engedélyezéséről"). ${ }^{9}$

1910-ben megkezdődtek a beruházások, amelynek keretében a szakasz felső torkolatánál hajózsilip és vízbeeresztő műtárgy épült. ${ }^{10}$ A létesített mütárgyak mellé 1954 és 1960 között megépítették a Kvassay-vízerőművet, amely két függőleges tengelyü, reverzibilis Kaplan-típusú turbinával üzemelt. Az RSD déli végén, Tassnál, 1926 és 1928 között hajózsilip, vízleeresztő zsilip és erőmű épült (Az 1956-os jeges árvíz következtében megrongálódott vízerőművet és vízleeresztő zsilipet elbontották. A vízlevezetés funkcióját a hajózsilip vette át.) A terepviszonyok miatt a Duna-ág árvízlevezetésre, árvízcsúcs-csökkentésre nem vehető igénybe. Megállapítható, hogy a rendszer a jelenlegi állapotához jól közelítő formáját a 19. század végét követő folyószabályozások és az 1910-1928 között létesített Kvassay- és Tassi- nagymütárgyak megépítését követően nyerte el.

Az 1960-as évektől, a tehetősebb fővárosi polgárok és a környékbeli lakosság részéről, növekvő igény mutatkozott az RSD vízparti területeinek felvásárlására. Megkezdődött a parti sávok, szigetek felparcellázása és értékesítése, amely napjainkban is meghatározza a környezet arculatát. A vízrendszerrel kapcsolatban egyre összetettebb igények jelentkeztek, amelyeket folyamatosan össze kell hangolni. Az érintettek számának növekedésével párhuzamosan fokozatosan előtérbe kerültek a vízminőségi és vízmennyiségi kérdések is. Az RSD Budapest négy kerületét, Pest megye 21 és Bács-Kiskun megye egy települését érinti. A komplett RSD közvetlenül 160-170 ezer föt, közvetve mintegy 250 ezer embert érint. A rendszer 25 ezer hektár öntözését biztosítja, és $1747 \mathrm{~km}^{2}$ területről gyűjti össze a belvizet. Vízbetáplálás a Kvassay-zsilip mellett, a Gyáli I. főcsatornán, illetve a kettős működésű Duna-Tisza csatornán és I. Árapasztó csatornán történik. ${ }^{11}$ Az RSD-ből több ponton történik vízkivétel, a Duna-völgyi föcsatorna mellett, a legjelentősebb a Kiskunsági főcsatorna öntözővízigénye ( $\left.15 \mathrm{~m}^{3} / \mathrm{nap}\right)$, amely Magyarország öntözésfejlesztési céljait vizsgálva egyre fontosabb szerepet fog kapni a Homokhátság öntözővíz-ellátásának vonatkozásában.

Az állandó vízbetáplálásnak az RSD-t terhelő tisztított és tisztítatlan szennyvizek hígítása és elkevertetése miatt jelentős szerepe van. Az RSD egyik funkciója a tisztított szennyvizek befogadása. A legjelentősebb terhelés a Dél-pesti Szennyvíztisztító Telepről a Népjóléti csatornán keresztül bevezetett tisztított szennyvíz (száraz időszakban 53 ezer $\mathrm{m}^{3} / \mathrm{nap}$ ). ${ }^{12} \mathrm{Az}$ RSD-rendszer komplexitását jól tükrözi, hogy egyaránt fontos funkciót tölt be az árvízvédelem, nagytérségi vízleadás, öntözés, belvízvédelem, rekreáció (horgászat, vízi sportok, fürdőhelyek), természetvédelem, hajózás és a tisztított szennyvizek befogadása terén is. A biztonságos üzemeltetés érdekében az igényeket össze kell hangolni. Az üzemeltetés az üzemeltetési szabályzatra épülve

9 1904. évi XIV. törvénycikk a magyar királyi államvasutak hálózatának kibővitéséről, vasuti és más beruházásokról, valamint a szükséges költségek engedélyezéséröl.

10 Sajó Elemér - Benedek József: A soroksári Dunaág felső kamarazsilipjének pályatervei és kiviteli terve. Vízügyi Közlemények, 1. (1911), 3. 145-174.

11 Pálfai Imre: A Duna-Tisza közi Hátság vízgazdálkodási problémái és megoldásuk lehetséges útjai. Vízügyi Közlemények, 77. (1995), 2. 144-165.

12 Dél-pesti Szennyvíztisztító Telep. FCSM.hu. 
az üzemeltetési engedély alapján történik. A Ráckevei (Soroksári) Duna-ág vízterületének vagyonkezelését a Közép-Duna-völgyi Vízügyi Igazgatóság látja el.

\section{A víztest állapotértékelése}

Az RSD állapotértékelésének vizsgálatához Magyarország felülvizsgált Vízgyűjtő-gazdálkodási Terve (VGT2) jelenti a kiindulási alapot.

A Víz Keretirányelv (VKI) előírásainak teljesítése érdekében a tagállamoknak intézkedési programokat kellett kidolgozni, vízgyűjtő kerületekre vonatkozó vízgyűjtő-gazdálkodási tervek formájában. A vizek állapotának minősítése a víztestek állapotértékelésén alapszik. Az állapotértékelést a VKI előírásai szerint az „egy rossz - mind rossz elv" alapján kell elvégezni. ${ }^{13} \mathrm{~A}$ VKI szerint a felszíni víztesteket ökológiai és kémiai állapot szerint kell minősíteni. Az integrált minősítési rendszer részletes felépítését a közleményben terjedelmi okok miatt nem tárgyaltam. A VGT2 alapján megállapítható, hogy az RSD egy erősen módosított felszíni víztest. Az RSD állóvízjellegű víztestnek minősül, vízgazdálkodási besorolása szerint tározó.

1. táblázat. RSD állapotértékelési eredménye

\begin{tabular}{|c|c|c|c|c|c|c|}
\hline $\begin{array}{c}\text { Biológiai } \\
\text { elemek }\end{array}$ & $\begin{array}{c}\text { Fizikai-kémiai } \\
\text { állapot }\end{array}$ & $\begin{array}{c}\text { Hidromorfológiai } \\
\text { állapot }\end{array}$ & $\begin{array}{c}\text { Specifikus szennyezők } \\
\text { szerinti állapot }\end{array}$ & $\begin{array}{c}\text { Ökológiai } \\
\text { állapot }\end{array}$ & $\begin{array}{c}\text { Kémiai } \\
\text { állapot }\end{array}$ & $\begin{array}{c}\text { Integrált } \\
\text { állapot }\end{array}$ \\
\hline gyenge & mérsékelt & kiváló & kiváló & gyenge & jó & gyenge \\
\hline
\end{tabular}

Forrás: a szerző szerkesztése a VGT2 adatai alapján

Az RSD az integrált minősítés alapján gyenge állapotú értékelést kapott a VGT2-ben. Megvizsgáltam az RSD minősítését a VGT1-ben, ahol szintén gyenge besorolást kapott. Kémiai állapotát tekintve elérte a jó állapotot, de az ökológiai gyenge állapot a VGT1-ben és a VGT2-ben egyaránt lerontotta az integrált állapotértékelés eredményét.

A VGT1 és a VGT2 eredményeinek összehasonlításából - javulás üteme alapján - valószínűsíthető, hogy a VKI-ban megfogalmazott jó állapot elérésének célja 2027-ig nem teljesíthető. Az RSD valós vízminőségi állapotát - a rendszer méreteiből adódóan - a valóságban nem lehetne egyszintű osztályozással deklarálni.

A rendszer vízminősége északról délre haladva fokozatosan javul. A víztest felső szakasza a Kvassay-zsilipen érkező vízbetáplálás hatására jelentős hordalékterhelésnek van kitéve, továbbá a Dél-pesti szennyvíztisztító telepről jelentős hozamú tisztított szennyvíz érkezik a rendszerbe. A víztest felső szakaszának magas a szervesanyag-terhelése. A vízminőség javítása érdekében, a különböző szennyvizek összetételével, az azok által jelentett problémák feltárásával és megoldásával már 1954-ben részletesen foglalkoztak, amit nagymértékben elősegített

13 Az Európai Parlament és a Tanács 2000/60/EK irányelve (2000. október 23.) a vízpolitika terén a közösségi fellépés kereteinek meghatározásáról. 
az átfogó vízgyűjtőfelmérés, a vízminőségi állapotfelvétel elkészítése. ${ }^{14} \mathrm{Az}$ RSD egyes részei jelentős mértékben feliszapolódtak, amelyek tovább nehezítik a vízminőségi állapot javítását. A Duna-ágat közvetlenül terhelő területhasználatok, azaz a parti sávban és a szigeteken található üdülőtelkekről (közel 8500 telek) származó szennyvizek jelentős vízminőségi problémát jelentettek a korábbi években. A vízminőség javítása érdekében elindult a parti sávok csatornázása, és az elmúlt években fokozatosan növekszik a rákötések száma, amely pozitív hatást gyakorolt a víztest állapotára. Az RSD középső és a felső szakaszán a vízminőségi állapot jelenleg még nem teszi lehetővé természetes fürdőhelyek biztonságos kijelölését. A déli részen viszont több fürdőhelyet kijelöltek ( $5 \mathrm{db}$ fürdőhely). A ráckevei strandon a fürdővíz minősítése már kiváló állapotú volt.

A „Ráckevei (Soroksári)-Duna-ág (RSD) és mellékágai kotrása, mütárgyépítés és -rekonstrukció" elnevezésű (KEOP-2.2.1/2F/09-2009-0002) KEOP pályázat keretében megvalósult az RSD-n egy vízminőségi monitoringrendszer kiépítése. A monitoring rendszer fő célja az RSD vízminőségének és vízháztartásának nyomon követhetősége, kimutatva a projekt részét képező műtárgyfejlesztések hatását a vízminőségre. A monitoringrendszer elősegíti az esetlegesen szükséges vízvédelmi beavatkozások megtételét.

A vízminőségi problémák szorosan összefüggnek a vízmennyiségi problémákkal, ezért ez a két meghatározó elem a megoldás szempontjából nem elkülöníthető. A minőségi és a mennyiségi kérdések együttes értékelése és kezelése elengedhetetlen.

A Duna folyószabályozása, az osztrák Duna-szakaszon épült vízlépcsők, illetve az 1970-es években történt mederkotrások maguk után vonták a Duna fömedrének süllyedését. A társadalom a vízminőségi és a vízmennyiségi problémákat egyaránt hajlamos egyszerüen az éghajlatváltozásra visszavezetni, pedig jelentős hatással lehetnek egyéb emberi beavatkozások is. A dunai fömeder süllyedése például alapvetően emberi beavatkozások hatására vezethető vissza. Ebből következik, hogy a vízszintek esésének elemzése sokkal komplexebb vizsgálat, mint egyszerüen a kevesebb csapadékmennyiségre visszavezetni az adott helyzetet. A meder-berágódásnak a kisvízszintek csökkenésére gyakorolt negatív hatása azért kritikus, mert felgyorsítja a mellékágak, holtágak elválását a főfolyástól. Az elszigetelődés fokozódása hosszú távon a mellékágak kiszáradásához, illetve pangó vízzé válásához vezet, amely magában hordozza a vízminőség devalválódását.

A 2018-as évet megelőzően a Duna budapesti szakaszán a mértékadó árvízi vízmércén, ismertebb nevén az „elrendelő vízmércén” (Vigadó tér) valaha mért legkisebb vízállás (LKV) $51 \mathrm{~cm}$ volt, amelyet még 1947-ben mértek. A Vigadó téri vízmérce nullpontja 94,960 mBf. A 71 éves, 1947. évi, kisvízi rekord először 2018. 10. 17-én (17:00) dőlt meg, majd 2018. 10. 25-én ismét új rekord alacsony vízállás alakult ki. Az új LKV 2018-ban 33 cm lett.

Az RSD állapotát negatívan befolyásoló kisvizes időszakok jelentősége miatt megvizsgáltam a legkisebb vízállásokat az 1989 és 2018 év közötti, statisztikai szempontból elfogadhatónak feltételezett 30 éves időszakra, éves bontásban (2. ábra). Az éves LKV-adatokat napi szinten mért részletességű adatforrásból származtattam.

14 Lesenyei József: A Soroksári Dunaág vízminőségi vizsgálata. Vízügyi Közlemények, 36. (1954), 1. 219-229. 


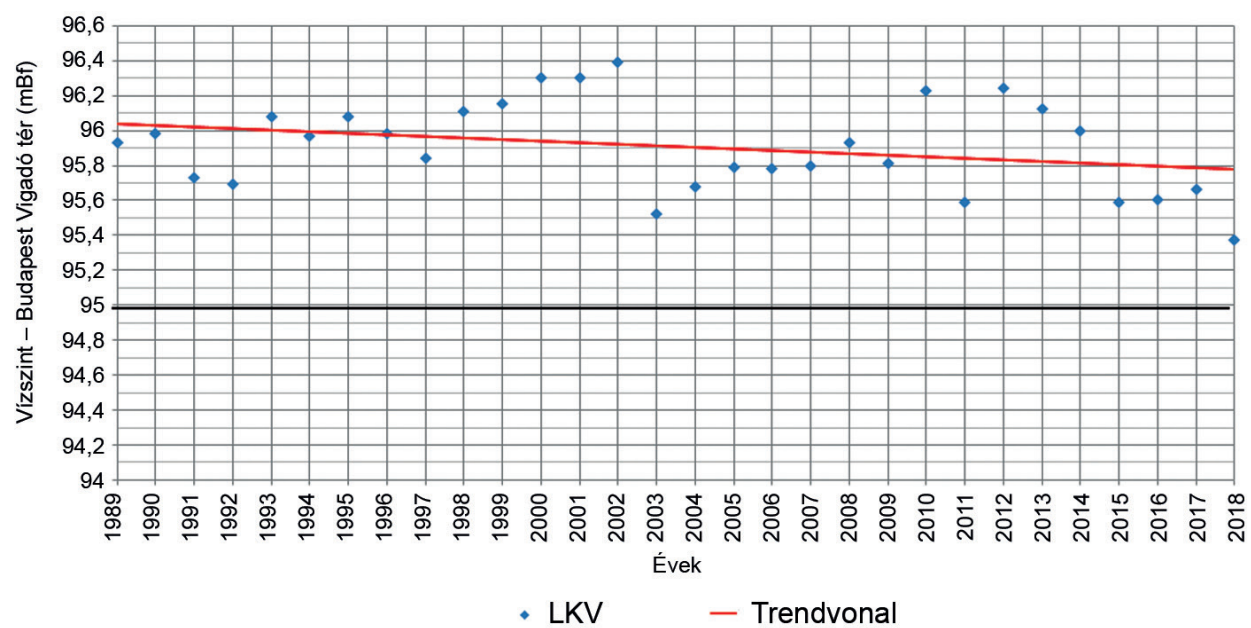

2. ábra. LKV éves bontásban 1989-2018 (mBf)

Forrás: a szerző saját szerkesztése

Az 1989-2018 közötti adatsor alapján, a 2. ábrát elemezve megállapítható, hogy az LKV-k alakulása csökkenő trendet mutat. Az RSD fejlesztésének és üzemeltetésének szempontjából, az LKV csökkenése mellett a másik mértékadó tényező a kisvizek gyakoriságának és tartósságának növekedése lehet.

\section{Fejlesztések}

A vízminőségi állapot hatékony javításához szükséges, rendszerszintű, komplex megoldások meghatározásához ismerni kell az RSD-t érintő jelenleg futó fejlesztéseket. A Fejlesztések címü fejezet célja az aktuális projektek rövid ismertetése. A vízrendszeren északról délre haladva gyűjtöttem össze a kiemelt fejlesztéseket. A Csepel-sziget északi csúcsánál található Kvassaymútárgycsoport rekonstrukciójának kivitelezése részben 2015-ben megvalósult.

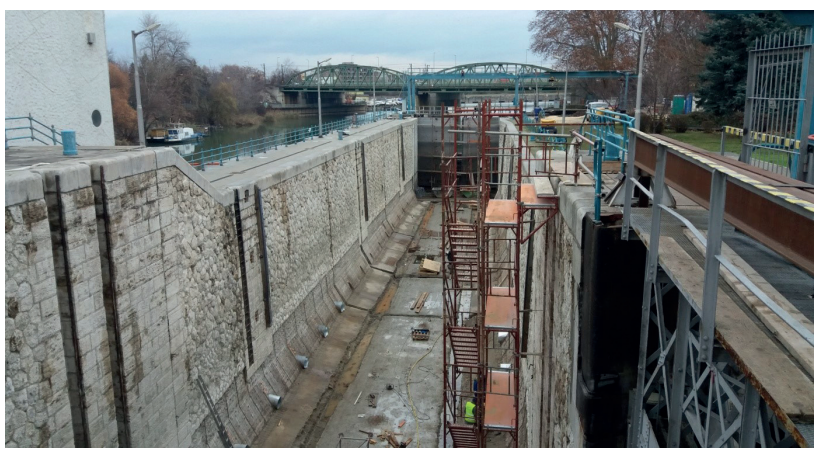

3. ábra. A Kvassay-hajózsilip rekonstrukciója

Forrás: a szerző felvétele 
A „Ráckevei (Soroksári)-Duna-ág (RSD) és mellékágai kotrása, műtárgyépítés és -rekonstrukció" elnevezésű KEOP-pályázat magában foglalta a vízbeeresztő zsilip elzáró berendezéseinek felújítását (acélszerkezetű elzárás rekonstrukciója). Ezen túlmenően meg kellett oldani a felvízi oldalról érkező uszadékok kiemelését, ezért gerébtisztító szerkezetegyüttes épült. A műtárgycsoport további rekonstrukciókra szorult, ezért 2018-ban elindult a „Nagymütárgyak fejlesztése és rekonstrukciója" címü (KEHOP-1.4.0-15-2015-00002) KEHOP-projekt keretében a hajózsilip-rekonstrukció kivitelezése. Emellett, 2018 végén elindult a meghibásodott Kaplan-turbinák kiemelése és felújítása is.

A Kiemelt Kormányzati Beruházások Központja Nonprofit Zrt. 2018-ban pályázatot hirdetett a dél-pesti és észak-csepeli komplex városfejlesztés megvalósításának céljából (Budapest Déli Városkapu Fejlesztési Program). ${ }^{15}$ A pályázat keretében az előzetes tervek szerint megvalósulna mintegy 12 ezer egyetemi hallgató lakhatásának biztosítása, továbbá sport- és rekreációs létesítmények épülnének, többek között egy 15 ezres atlétikai stadion (4. ábra).

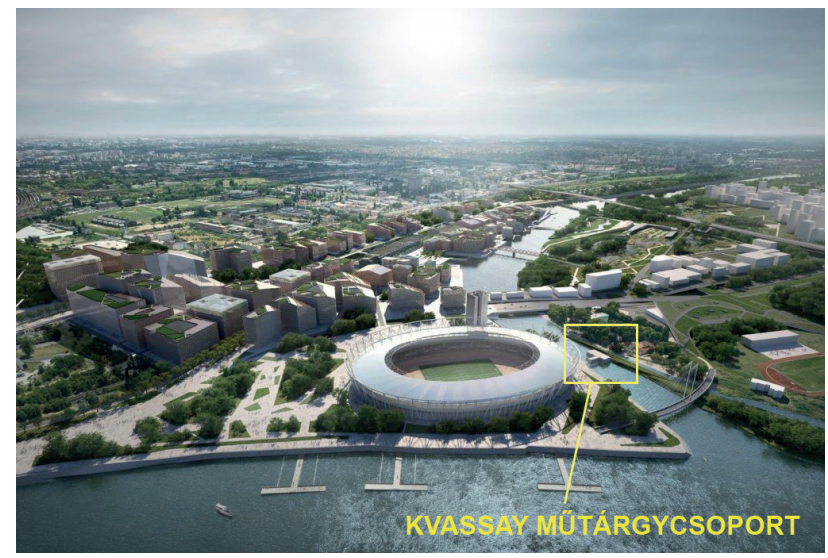

4. ábra. A Déli Városkapu-fejlesztés nyertes pályázatának látványterve

Forrás: Nyertesek. Delivaroskapu.org.

A 4. ábrán látható a Kvassay-műtárgycsoport is. A Kemény Ferenc Sportlétesítmény-fejlesztési Program keretében, az RSD-n (Francia-öböl), megépül a Dunai Evezős Központ, ahol a pálya alkalmas lesz nemzetközi versenyek lebonyolítására. A pályázat szerint „kiemelendően fontos aspektus a város és víz kapcsolatának erősítése, élettel teli közösségi terek létrehozása". A megfogalmazott célokból adódóan is, a fejlesztések eredményessége tekintetében kiemelten fontos funkciót fog betölteni a Kvassay-mütárgy, mivel ezen keresztül fog történni a rendszerbe való vízbetáplálás.

Az RSD vízminőségi állapotjavításának vizsgálatakor megkerülhetetlen a Dél-pesti Szennyvíztisztító Telep (DPSZT). A DPSZT-re egyesített csatornarendszeren keresztül érkezik a szenynyvíz a Torontál utcai főgyűjtőből. Pestlőrinc, Kispest, Erzsébet és Soroksár hozzávetőlegesen 300 ezer lakosának, valamint a területen müködő vállalkozásoknak a szennyvizét fogadja

15 Budapest Déli Városkapu Fejlesztés Tervpályázat. 
és tisztítja. A tisztítótelep névleges biológiai tisztítókapacitása $80000 \mathrm{~m}^{3} /$ nap, tényleges terhelése 53000 m³/napra becsülhető. A DPSZT-ből a Népjóléti-árkon keresztül érkezik a tisztított szennyvíz az RSD-be. A Dél-pesti szennyvíztisztító telep jelenlegi 3 rekeszből álló záportározó medence bővítésére elkészültek a tervek és kiírták az építési pályázatot. A zápormedence hozzávetőlegesen $7000 \mathrm{~m}^{3}$ kapacitásra történő bővítése 2019-ben valósult meg. Emellett a meglévő kiviteli engedélyes tervek alapján, a Népjóléti-árokban várhatóan kialakítanak egy rácsszemét visszatartására alkalmas mütárgyat, amely a csapadékos idei üzemállapotban túlfolyó záporvizek szürésére szolgálna.

Az RSD-t terhelő kommunális eredetű szennyvizek témakörének tárgyalásakor vizsgálni kell a Duna-ág parti sávjaiban és a szigeteken keletkező kommunális vízhasználatból származó vízszennyező anyagok kivezetését. A „Ráckevei (Soroksári) - Duna-ág vízgazdálkodásának, vízminőségének javítása: szennyezőanyagok kivezetése a parti sávból" címü (KEOP2.2.1/2F/09-2010-0002) KEOP-projekt keretében 2015-ben megvalósult 14 önkormányzat üdülőterületén a gerincvezetékek fektetése, valamint átemelők létesítése. A telken belüli magánhálózatok kiépítése folyamatos, a rákötések száma fokozatosan növekszik. A projekt keretében több mint 7500 bekötés valósult meg.

Az RSD-t a Csepel-sziget déli végén a Tassi-zsilip határolja. A „Ráckevei (Soroksári) Duna-ág és mellékvizeinek kotrása, mütárgyépítés és -rekonstrukció" elnevezésű (KEHOP-1.3.1-15-2015-00002) KEHOP-projekt keretében 2018-ban kezdetét vette a Tassi többfunkciójú vízleeresztő műtárgy kivitelezése (5. ábra).

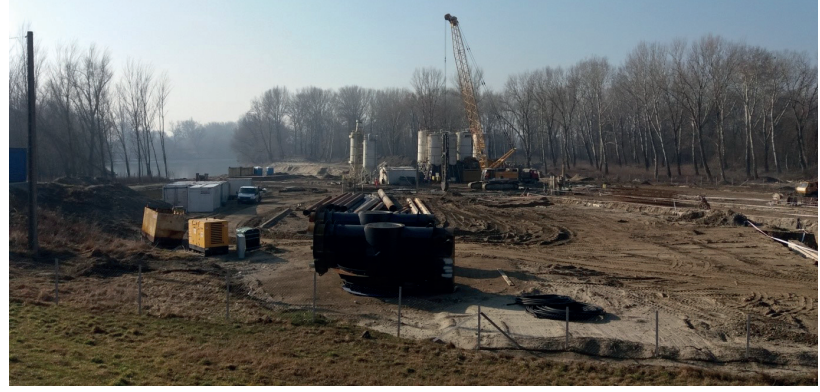

5. ábra. A Tassi többfunkciójú vízleeresztő mútárgy kivitelezése

Forrás: a szerző felvétele

A mútárgyat a meglévő Tassi-hajózsiliptől északnyugatra, mintegy 250 m távolságra a Duna elsőrendű árvízvédelmi töltésébe építik be. A műtárgyépítés töltésáthelyezéssel is jár. A tervezett mütárgy látványtervét a 6 . ábra szemlélteti. 


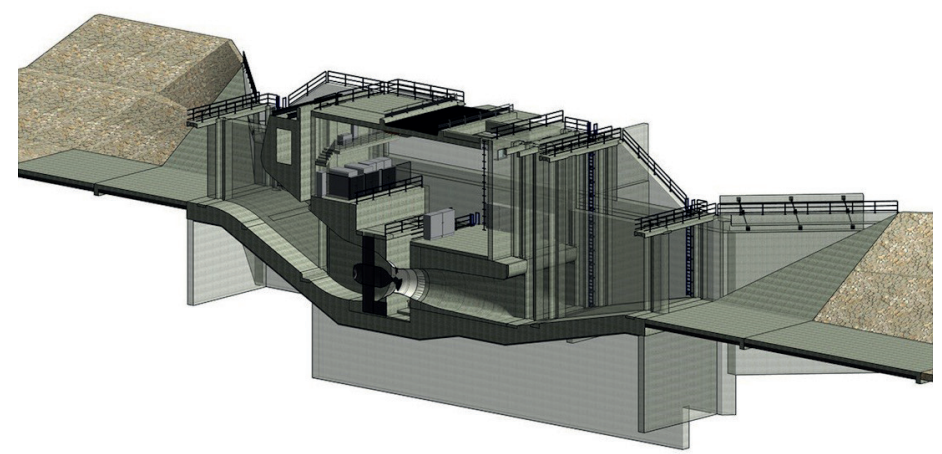

6. ábra. A Tassi többfunkciójú vízleeresztő mütárgy látványterve

Forrás: Rsd.ovf.hu.

A Tassi-mütárgy építése kiemelten fontos a Duna-ág biztonságos és a megfelelő vízmennyiséget és vízminőséget garantáló üzemeltethetősége szempontjából. A műtárgy megépítésével és üzemével nő a tápvíz mennyisége, ami a jelenleginél kiegyensúlyozottabb vízbetáplálást jelent, tehát azt, hogy a szélsőséges dunai vízállástartományokban is biztosítható a rendszer vízcseréje, vízfrissítése.

\section{Komplex tervezés}

A vízrendszer kiterjedéséből és komplexitásából adódóan a jövőbeli fejlesztéseknél nagy beruházási és üzemeltetési költségekkel kell kalkulálni. A rendszer müködésébe történő egyes beavatkozások visszahatnak egymásra. A hatékony kockázatkezelést és forrásfelhasználást a rendszer összetettsége miatt kizárólag stratégiai szemléletű komplex tervezéssel lehet eredményesen megvalósítani.

Mi az a komplex megoldási lehetőség, amire szükség lenne az RSD vízminőségi állapotának javításához? Az RSD felépítésének, működésének vizsgálatakor arra a következtetésre jutottam, hogy a szükséges jövőbeli fejlesztések rendszerszinten hatékony megvalósításához el kellene készíteni egy döntés-előkészítő komplex tanulmányt.

A tanulmányban fel kell tárni és elemezni a különböző alternatívákat és beavatkozási lehetőségeket. Az integrált elemzésnek a különböző alternatívák vizsgálata során, a műszaki lehetőségek figyelembevétele mellett magában kell foglalnia a környezeti és gazdasági szempontokat. A szempontrendszer fontos részét kell hogy képezze az előzetes költségbecslés. Az RSD fejlesztési lehetőségeinek vizsgálata során arra a következtetésre jutottam, hogy a javasolt tanulmány készítésénél kritikus szerepe van az egyes alternatívák megvalósítási időigényének, illetve az időbeli ütemezésnek. 
A komplex tanulmányban javaslom, hogy határozzák meg az RSD rendszerére értelmezett vízgazdálkodási célkitüzéseket. A célok, igények ismeretében szükség lenne a vízrendszer teljes hidrológiai elemzésére. A hatékony jövőbeli fejlesztések megvalósításához, a jelenleg futó fejlesztések számbavétele mellett, elöre kell becsülni a Duna várható további medersüllyedését és a tervezett öntözésfejlesztés hatására megnövekvő vízszolgáltatási igényeket.

A hidrológiai helyzet mellett elengedhetetlen a vízminőség és az ehhez társuló követelmények vizsgálata. Az RSD vízminőségét jelentősen befolyásolja az előző fejezetben bemutatott DPSZT, ezért a jövőbeli fejlesztési lehetőségek vizsgálatakor ezt javasolt kiemelten kezelni. A DPSZT - RSD vízminőségére gyakorolt - negatív hatásának oka két meghatározó részből áll, egyfelöl a száraz idei normál üzemállapotból, másfelől a csapadékos idei üzemállapotból származó terhelés. A tanulmányban olyan megoldási alternatívákat kell összevetni, illetve esetlegesen kombinálni, mint a szennyvíztisztítási technológia fejlesztése, egyesített rendszer egyes részeinek leválasztása, átvezetés vagy éppen a tisztított szennyvíz újrahasznosítása.

A mennyiségi és a minőségi alapokra modellvizsgálatok alkalmazásával lehetne felépíteni egy jól strukturált intézkedési tervet. A fenti tartalommal a teljes vízrendszerre elkészíthető tanulmány hozzájárulna a rendszer még hatékonyabb üzemeltetésének megalapozásához. A javasolt tanulmánykoncepció elsődleges funkciója a döntéstámogatás. A koncepció elősegíti a hatékony forrásfelhasználás igazolhatóságát, hozzájárulva a finanszírozási lehetőségek biztosításához.

\section{Következtetések}

Az RSD-t az üzemeltetés és a jövőbeli fejlesztések szempontjából komplex rendszerként kell kezelni.

A különböző igényeket hosszú távú stratégia mentén kell összehangolni.

A rendszer működésébe történő beavatkozások visszahatnak egymásra, ezért kritikus kérdés a forrásfelhasználás hatékonyságának biztosítása.

A klímaváltozás tükrében dinamikusan változó igények, illetve tervezési körülmények hatására sérülhet a rendszer funkciójának ellátása.

A feldolgozott mérések alapján az LKV egyértelmüen csökkenő trendet mutat a budapesti Vigadó téri vízmérce vonatkozásában.

A hatékony kockázatkezelést és forrásfelhasználást a rendszer összetettsége miatt kizárólag stratégiai szemléletű komplex tervezéssel lehet eredményesen megvalósítani.

Javaslom egy döntés-elökészítő komplex tanulmány elkészítését. A tanulmánynak ki kell terjednie minden lehetséges üzemállapotra.

A tervezés során kritikus pont a beavatkozások költségvonzata és az ütemezés. 


\section{Felhasznált irodalom}

1870. évi X. törvénycikk a Duna-folyamnak a föváros mellett szabályozásáról s a forgalom és közlekedés érdekében Buda-Pesten létesitendő egyéb közmunkák költségeinek fedezéséről és e közmunkák végrehajtási közegeiröl. Online: https://net.jogtar.hu/ezer-ev-torveny?docid=87000010.TV\&searchUrl=/ezer-ev-torvenyei?keyword=1870.+\%C3\%A9vi+X.+t\%C3\%B6rv\%C3\%A9nycikk

1904. évi XIV. törvénycikk a magyar királyi államvasutak hálózatának kibővitéséröl, vasuti és más beruházásokról, valamint a szükséges költségek engedélyezéséröl. Online: https://net.jogtar. hu/getpdf?docid=90400014.TV\&targetdate=\&printTitle=1904.+\%C3\%A9vi+XIV.+t\%C3\%B6rv\%C3\%A9nycikk\&referer $=1000 \mathrm{ev}$

Az Európai Parlament és a Tanács 2000/60/EK irányelve (2000. október 23.) a vízpolitika terén a közösségi fellépés kereteinek meghatározásáról. Online: https://eur-lex.europa.eu/legal-content/ HU/LSU/?uri=celex:32000L0060

Budapest Déli Városkapu Fejlesztés Tervpályázat. Online: https://delivaroskapu.org/

Csányi Béla - Juhász Péter - Tyahun Szabolcs: A Ráckevei Soroksári Duna makroszkópikus vízi gerincteleinek vizsgálata. Vízügyi Közlemények, 84. (2002), 2. 174-193.

Dél-pesti Szennyvíztisztító Telep. FCSM.hu. Online: www.fcsm.hu/

Jelentös vízgazdálkodási problémák - Duna-völgyi-föcsatorna vízgyüjtö-gazdálkodási tervezési alegység. Online: www4.vizugy.hu/old_vizugy_site/documents/132D0778-308D-4E47-B3C849224DC3DFC4/1_10_Duna_volgyi_focsatorna_JVP_vegleges.pdf

Lesenyei József: A Soroksári Dunaág vízminőségi vizsgálata. Vízügyi Közlemények, 36. (1954), 1. 219-229. Nyertesek. Delivaroskapu.org. Online: www.delivaroskapu.org/nyertesek

Operatív vízállások. Vízügyi Honlap. Online: www.vizugy.hu/

Papanek László: Az újonnan épülő vízleeresztő mütárgy szerepe a Ráckevei/Soroksári/Duna-ág vízgazdálkodásában. Előadás. Online: https://docplayer.hu/152272365-Az-ujonnan-epulo-vizleereszto-mutargy-szerepe-a-rackevei-soroksari-duna-vizgazdalkodasaban-papanek-laszlo-c-egyetemi-docens-osztalyvezeto-kdvvizig.html

Pálfai Imre: A Duna-Tisza közi Hátság vízgazdálkodási problémái és megoldásuk lehetséges útjai. Vízügyi Közlemények, 77. (1995), 2. 144-165.

Répássy Miklós: Az angolnáról. Halászat, 3. (1902), 1. 93-95.

Rsd.ovf.hu. Online: http://rsd.ovf.hu/galeria.html

Sajó Elemér - Benedek József: A soroksári Dunaág felső kamarazsilipjének pályatervei és kiviteli terve. Vízügyi Közlemények, 1. (1911), 3. 145-174.

Vadadi-Fülöp Csaba - Mészáros Gergely: A Ráckevei-Soroksári Dunával kapcsolatos zooplankton és makrogerinctelen kutatások áttekintése. Hidrológiai Közlöny, 87. (2007), 3. 60-63. 